\title{
Movimento negro e as lutas contra o racismo
}

\author{
Black movement and the struggles against racism
}

Carlos Benedito Rodrigues da SILVA ${ }^{1}$

\begin{abstract}
Resumo
Pretende-se apresentar neste artigo uma breve análise sobre as trajetórias do movimento negro no Brasil, tecendo consideraçôes sobre os mecanismos acionados, individual ou coletivamente, pelos negros brasileiros no enfrentamento das práticas discriminatórias. No primeiro momento, procura-se analisar o processo organizativo desse movimento em suas especificidades, no contexto dos movimentos sociais. Posteriormente, são traçadas considerações sobre a atuação de ativistas do movimento social negro em órgãos estatais e os diálogos estabelecidos para definição das políticas de combate ao racismo. Finaliza-se tecendo algumas consideraçóes sobre o racismo institucional como um entrave à aplicação das políticas públicas afirmativas e ao cumprimento da Lei $10.639 / 03$, que determina a introdução do ensino das culturas africanas e afro-brasileiras no sistema educacional brasileiro.
\end{abstract}

Palavras-Chave: Movimento Negro. Participação Política. Resistência Negra. Racismo Institucional.
Abstract

I intend to present in this article, a brief analysis on the trajectories of the black movement in Brazil, making considerations about the mechanisms applied, individually or collectively by the Brazilian blacks in the confrontation with the discriminatory practices. In the first moment, I try to analyze the organizational process of this movement in its specificities in the contesto of the social movements. Subsequently, I will make considerations about the activities of activists of the black social movement state bodies, and the dialogues established for the definition of policies to combat racism. I conclude with some considerations on institutional racism as an obstacle to the implementation of affirmative public policies and compliance with Law 10.639 / 03 that determines the introduction of the teaching of African and Afro-Brazilian cultures in the Brazilian educational system

Keywords: Black Movement. Political Participation. Black Resistance. Institutional Racism.

1 Departamento de Sociologia e Antropologia. Núcleo de Estudos Afro-Brasileiros-NEAB. Programa de Pós-Graduação em. Ciências Sociais-UFMA. Doutor em Antropologia. Coordenador do Núcleo de Estudos Afro-Brasileiros da Universidade Federal do Maranhão. Avenida dos Portugueses 1966, Cidade Universitária do Bacanga, São Luís/MA.CEP: 65080-805. Tel.: (98)3272-8352/3. Email: <cbrodriguesilva@gmail.com>.

R. Educ. Públ.

Cuiabá

\begin{abstract}
v. 27
\end{abstract}
n. $65 / 2$ p. $613-634$ maio/ago. 2018 


\section{Introdução}

A exemplo de outras naçóes, o Brasil passa, neste início de século XXI, por uma série de transformaçóes nos mais diversos campos, especialmente, com a explicitação de contradiçôes desencadeadas pelo processo de globalização. Entre diversos temas que têm ocupado as pautas de debates nesse processo, a questão étnico-racial tem estimulado diálogos entre os movimentos sociais, a academia e o Estado, com vistas à formulação de políticas eficazes de combate às desigualdades e ao racismo. A questáo pautada, tanto pela intelectualidade negra acadêmica, quanto pelo ativismo político, é que, sem promover melhorias nas condiçóes de vida da totalidade da população, sem que o país resolva a lacuna secular de desigualdades raciais, não haverá progresso possível.

Desde o pós-abolição, no final do século XIX, quando o debate sobre a chamada questão do negro no Brasil veio à tona, com a preocupação das elites sobre os destinos do país diante das transformaçóes socioeconômicas que exigiam o ingresso qualificado na nova ordem econômica, somente na segunda metade do século XX, após a realização da Marcha Zumbi dos Palmares contra o racismo pela cidadania e pela vida ${ }^{2}$, o Governo Federal encampou o debate público em torno da elaboração de políticas públicas de superação das desigualdades raciais. Em 1996, com a realizaçâo do seminário internacional Multiculturalismo e Racismo, organizado pelo Departamento de Direitos Humanos do Ministério da Justiça, o então presidente, Fernando Henrique Cardoso, reconheceu que o racismo, como elemento estruturante da sociedade brasileira, constitui um entrave às oportunidades de acesso ao trabalho e a condiçôes dignas de moradia, saúde e educação para a maioria da população brasileira, exigindo, portanto, açóes também institucionais de enfrentamento.

Em função disso criamos um grupo interministerial. Para dar uma injeção de criatividade às nossas práticas, até mesmo nas práticas legislativas e burocráticas, na maneira pela qual o governo atua nessa matéria, que é difícil atuar, porque diz respeito a valores muito profundos e interesses também... situaçôes inaceitáveis, pois a discriminação parece consolidarse como alguma coisa que se repete, que se reproduz. Não se pode esmorecer na hipocrisia e dizer que o nosso jeito é esse.

2 A Marcha Zumbi pela Cidadania e Pela Vida ocorreu em 20 de novembro de 1995, organizada pelo movimento social negro, com representação de outros movimentos sociais do país, denunciando o racismo como uma das principais causas de exclusão dos negros na sociedade brasileira e exigindo, por meio de documentos entregues ao presidente da República, açōes concretas do governo no combate ao racimo. 
Não, o nosso jeito está errado mesmo, há uma repetição de discriminaçôes e há a inaceitabilidade do preconceito. Isso tem de ser desmascarado, tem de ser, realmente, contra-atacado, não só verbalmente, como também em termos de mecanismos e processos que possam levar a uma transformação, no sentido de uma relação mais democrática entre as raças, entre os grupos sociais, e entre as classes. (CARDOSO, 1997, p. 16) .

Embora possamos focalizar essas iniciativas nas últimas décadas do século $\mathrm{XX}$, para as organizaçóes do movimento social negro esse debate não é novo. As lutas pelo reconhecimento da importância histórica e por políticas públicas para a população negra são recorrentes na trajetória das organizaçôes negras brasileiras. Há décadas, homens e mulheres, ativistas do movimento social negro, reivindicam o reconhecimento da nossa importância no processo histórico de desenvolvimento do Brasil, seja do ponto de vista da produção agropecuária e canavieira, da arquitetura ou das artes, da culinária, das crenças e afetos, da produçáo e do comércio, de uma cultura ricamente pluralizada, forjada com os saberes milenares trazidos nas memórias das gentes negras que se transportaram para cá, fatos que a história oficial ainda insiste em apagar. Da mesma forma que há décadas o ativismo negro organizado politicamente reivindica ao Estado a definição de medidas, seja ao nível educacional, seja no mercado de trabalho, de reparação dos prejuízos sofridos ao longo da história nacional pelos descendentes de africanos escravizados.

\section{Resistência ao escravismo}

Segundo o saudoso historiador negro Joel Rufino dos Santos.

A luta organizada contra o racismo nasce às vésperas da Revolução de Trinta, semi-intelectuais e subproletários se juntam em são Paulo 'numa imprensa negra'. Jornais como O Clarim da Alvorada e O Getulino, de Campinas denunciavam as discriminaçóes raciais mais chocantes do nosso quadro urbano no emprego, na moradia, na educaçáa, nos locais de lazer. Foi essa imprensa o embriāo da primeira instituição de luta contra o racismo

3 Pronunciamento de abertura do entâo Presidente da República Fernando Henrique Cardoso, no Seminário Multiculturalismo e Racismo: o papel da ação afirmativa nos Estados democráticos contemporâneos. Publicado por Souza Jessé. In Multiculturalismo e Racismo: uma comparaçáo Brasil- Estados Unidos. Ministério da Justiça. Secretaria Nacional de Direitos Humanos. Brasília-DF. 1997. 
brasileiro - apresentado então, eufemisticamente, como discriminação racial - a Frente Negra Brasileira. (SANTOS, 2015.p.16, grifos nossos).

Mesmo considerando que as organizaçóes políticas do movimento social negro só emergem no cenário nacional no início do Século XX, com a imprensa negra e a Frente Negra Brasileira (abordarei mais adiante sobre a FNB), é preciso reconhecer que desde o período escravista essas mobilizaçóes já estavam presentes, engendrando formas de resistência diversas, seja do ponto de vista individual, como as fugas e suicídios (MATTOSO, 2001), seja com a resistência coletiva, materializada nas lutas abolicionistas, nos templos religiosos de matrizes africanas, nas irmandades religiosas cristâs ou na formação dos quilombos.

A maior representação de resistência que se tem notícia nesse período é a formação do quilombo de Palmares no Século XVII, como resultado de fugas coletivas. Palmares foi, por quase um século a sede do mais duradouro e mais conhecido símbolo da resistência contra a escravidão no Brasil. Uma organização social formada por negros fugidos da escravidão, além de índios e mestiços (ALVES FILHO, 1988), com um nível de produção diversificada, contrastando com a rigidez da monocultura, constituindo uma alternativa de vida livre para todos os segmentos explorados, que ameaçavam e punham em risco a empreitada colonial.

Para Moura (2004, p. 347), “[...] foi à maior manifestaçấo de rebeldia e organização política, militar e econômica contra o escravismo na América Latina [...]", resistindo pouco mais de um século (1595 a 1695) a várias investidas das milícias do Governo Geral de Pernambuco, na tentativa de desestabilizar as estruturas quilombolas palmarinas. A organização militar de Palmares, nos mostra Clóvis Moura (1983), estava estruturada para defender coletivamente a República, daí a insurgência de Zumbi e seus seguidores contra as tentativas de negociação de Ganga Zumba ${ }^{4}$, que significaria um retorno ao status de escravizado. Por isso, diz ele:

4 Ganga-Zumba foi o primeiro chefe conhecido do Quilombo de Palmares. Era tio de Zumbi e celebrizouse por ter assinado um tratado de paz com o governo de Pernambuco. Em 1678, o governador Pedro de Almeida fez a primeira proposta de paz a Ganga-Zumba, oferecendo uniäo, bom tratamento e terras, além de prometer devolver as mulheres e filhos de negros que estivessem em seu poder. Em troca da paz, os palmarinos pediam liberdade para os nascidos em Palmares, permissão para estabelecer comércio e trato com os moradores da regiáo e um lugar onde pudessem viver sujeitos às disposiçóes da autoridade da capitania. Prometiam entregar os escravos que dali em diante fugissem e fossem para Palmares. Em novembro do mesmo ano, Ganga-Zumba foi a Recife assinar o acordo. É cedida a ele e seus partidários a regiâo de Cucaú, distante $32 \mathrm{~km}$ de Serinhaém. Parte dos palmarinos, liderados por Zumbi, são contrários ao acordo de paz e se recusam a deixar Palmares. Em Cucaú, vivendo sob forte vigilância da autoridade portuguesa e hostilizado pelos moradores das vilas próximas, Ganga-Zumba vê frustrada sua iniciativa. Morreu envenenado por um partidário de Zumbi (ALVES FILHO, 1988). 
Zumbi não apareceu por acaso. Foi a síntese da capacidade de organização de resistência da República, o seu herói símbolo porque sintetizou na sua biografia, a biografia do povo que ele representou e pelo qual deu a vida. (MOURA, 1983, p. 120).

Segundo ainda Joel Rufino dos Santos (2015, p. 30) o quilombo constituíase na mais avançada forma de rejeição às regras do escravismo colonial, "[...] como símbolo exato da rebeldia negra”. Esse historiador sugere que é necessário problematizar as duas lideranças que se confrontam nas lutas palmarinas, Ganga Zumba e Zumbi. No imaginário do movimento social negro contemporâneo, o primeiro é desprezado como traidor, porque firmou a paz com o governo de Pernambuco em 1678, ao passo que o segundo se torna o herói estampado nas bandeiras de lutas contra o racismo. Para ele, essas duas situaçóes emblemáticas revelam, também, o dilema enfrentado pelos intelectuais militantes do movimento social negro no Brasil

Para os movimentos negros, o grande obstáculo tem sido este: apontam o caminho de Zumbi a massas que preferem viver como Ganga Zumba, sendo eles mesmos num certo sentido, liderados por intelectuais militantes que mostraram em sua vida pessoal capacidade em manejar as regras do sistema capitalista para se ajustar e vencer. (SANTOS, 2015, p. 31).

Analisando as formas de resistência negra ao escravismo, Moura (1988) enfatiza que os negros demonstraram um espírito associativo no Brasil, desde os primeiros tempos do escravismo, sem o qual não teriam sobrevivido à escravidão nem ao racismo no pós-abolição.

Além dos quilombos, que se espalharam pelo Brasil como resultados de fugas coletivas, também os terreiros de candomblé e outras expressóes da religiosidade de matriz africana, como as Irmandades Religiosas Cristãs, Congados e Batuques, constituem espaços importantes, por meio dos quais se produziram alternativas de sociabilidade, acobertamento de escravizados fugidos e até resignação espiritual e tolerância às angústias da escravidão (MOURA, 1983).

Muitas dessas organizações ultrapassaram as fronteiras do período escravista, permanecendo ativas na atualidade, com estruturas familiares hierarquizadas, seja no plano biológico, seja no espiritual, contribuindo com o fortalecimento da autoestima de grupos e com açóes importantes para a revitalização das heranças culturais africanas no Brasil. 


\title{
Organizações negras pós-abolição
}

Retomando ao esboçado no início deste artigo, é possível dizer que a Frente Negra Brasileira (FNB) é reconhecida como uma das primeiras organizaçóes do movimento negro no país. Mesmo considerando a interpretação de alguns autores e de militantes das esquerdas de que essa organização estaria reproduzindo os valores sociais e atitudes impostas pela ideologia do branqueamento, a FNB teve um papel importante, seja do ponto de vista da denúncia contra o racismo, seja pelo fortalecimento da consciência negra e também pelo estímulo ao processo de ascensão social dos negros, conforme mostram Marcio Barbosa e Aristides Barbosa (1998, p. 12):

\begin{abstract}
A Frente Negra Brasileira ofereceu à populaçáo negra marginalizada, possibilidades de organização, educação e ajuda no combate à discriminação racial. Foi, sem dúvidas, conservadora, expressava aspiraçôes de negros de classe média e teve concepçóes políticas limitadas, mas tentou dar aos afro-brasileiros, condiçôes de se integrarem à sociedade capitalista e conseguiu resposta popular, como prova o [grande número de filiais que estabeleceu e de associados que conquistou.
\end{abstract}

Sua fundação deu-se em 16 de setembro de 1931. O objetivo era unificar nacionalmente a luta das entidades negras que atuavam em várias regióes do país, com núcleos em São Paulo, Bahia, Pernambuco, Espírito Santo, Rio de Janeiro, Minas Gerias e Rio Grande do Sul. Segundo Clóvis Moura (1983) a FNB chegou a ter 70 mil filiados e seus membros possuíam uma carteira de sócio que os identificava como homens de bem com as autoridades. Durante os seis anos de sua existência, a FNB promoveu atividades antirracistas, com desfiles e passeatas, cursos profissionalizantes e reivindicações nos órgãos públicos para admissáo de negros e negras no mercado de trabalho, a exemplo do acesso que obtiveram na Guarda Municipal de São Paulo, que, até então, não aceitava negros em seus quadros.

A divulgação e o chamamento para as açóes ficavam por conta do jornal A Voz da Raça, criado em 1933. Em face do seu êxito organizativo, em 1936, a FNB registrou-se como partido político, topando de frente com o golpe do Estado Novo de Getúlio Vargas, em 1937, que a fechou, com os demais partidos políticos da época.

Como diz Florestan Fernandes. 
A Frente Negra Brasileira foi a expressão de tendências profundas, que se agitavam no meio negro e exigiam transformaçóes substanciais, a longo termo, do comportamento, da personalidade e do estilo de vida da gente negra... serviu como ponto de referência das primeiras formas e objetivaçáo social daquelas tendências... abrindo novas sendas à influência ideológica dos movimentos reivindicatórios e provocando avanços que não se fariam a não ser sob a pressão emocional ou moral da própria ação reivindicatória. (FERNANDES, 1978, p. 53).

Por outro lado, Abdias Nascimento e Eliza Larkin Nascimento, embora reconhecendo sua importância, não pouparam críticas às posturas frentenegrinas, enfatizando que:

A Frente Negra Brasileira representava sem dúvidas a maior expressão da consciência política afro-brasileira da época, consciência essa formada ao reagir contra o mais evidente aspecto do racismo, a sistemática segregação e exclusão à base de critérios raciais. Travava-se de uma consciência e uma luta de caráter integracionista, à procura de um lugar na sociedade 'brasileira', sem questionar os parâmetros euro-ocidentais dessa sociedade nem reclamar uma identidade específica cultural, social ou étnica. (NASCIMENTO; LARKIN NASCIMENTO, 2000, p. 206, grifo nosso).

Outra organizaçáo importante nas lutas do povo negro para superar os mecanismos de exclusão étnico-racial foi o Teatro Experimental do Negro (TEM), encabeçado por ele em 1944, onde as estratégias de qualificação recaem sobre a arte e a educação. O TEN constitui a primeira iniciativa para revolucionar a arte dramática brasileira, que até entáo só abria espaços para a atuação de artistas brancos, pois, segundo seu criador, a discriminação racial impedia que o negro frequentasse espaços sociais como o Tetro Municipal, a não ser para fazer a limpeza depois dos espetáculos.

O Teatro Experimental do Negro (TEM) nasceu para contestar essa discriminação, formar atores e dramaturgos afro-brasileiros e resgatar uma tradição cultural cujo valor foi sempre negado ou relegado ao ridículo pelos nossos 
padrôes culturais: a herança africana na sua expressão brasileira [...] continuava a tradiçáo de protesto e organização político-social, mas integrava a essa dimensão a reivindicação da diferença: o negro não procurava apenas integrar-se à sociedade branca [...] Ao contrário, reivindicava o reconhecimento do valor civilizatório da herança africana [...] exigindo que a diferença deixasse de ser transformada em desigualdade. (NASCIMENTO; LARKIN NASCIMENTO, 2000, p. 206).

Nessa linha de atuação, o TEN contribuiu com a intensificação dos debates sobre as relaçóes étnico-raciais no Brasil, apresentando propostas de combate ao racismo por meio de medidas culturais e educativas (GUIMARÃES; HUNTLEY, 2000; FERNANDES, 1978; MOURA, 1983; SANTOS, 2014), constituindo-se numa das mais importantes organizaçóes negras nas lutas contra o racismo na Segunda República, formando atores e atrizes comprometidos com essas lutas e promovendo um resgate da memória africana na sociedade brasileira, invisibilizada pelo eurocentrismo.

\section{Anos 70: negritude e identidade racial}

A partir dos anos 70 do século XX, o movimento social negro se apresenta com bases mais politizadas de reivindicaçóes, num movimento de amplitude nacional, revitalizando a discussão sobre negritude e identidade negra no Brasil. Esse novo modelo de organização já mereceria atenção dos estudos acadêmicos desenvolvidos desde anos 50 do século XX com a chamada missáo da UNESCO, que veio ao Brasil para estudar as relaçôes raciais, sob a coordenação de Roger Bastide e Florestan Fernandes.

Suas pesquisas analisavam as mudanças sociais provocadas pela industrialização e seus efeitos sobre as possibilidades de ascensão social do negro no Sudeste do Brasil, ao mesmo tempo em que traziam o movimento social negro para o cenário dos estudos acadêmicos, conforme mostra Flávia Mateus Rios (2009), analisando em recente artigo as relaçóes entre o movimento negro e a produção acadêmica das Ciências Sociais:

As primeiras investigaçóes empíricas sobre o movimento negro brasileiro do século XX aparecem nos estudos de relaçôes raciais, especialmente àqueles encomendados 
pela UNESCO na década de 1950. As formas diversas de interpretação desse movimento social estáo diretamente ligadas á visão que os autores tinham das relaçôes entre negros e brancos no Brasil. (RIOS, 2009, p. 263).

Mas é preciso constatar, ainda, que a redefinição das formas e atuação do movimento social negro dos anos 1970 resultou tanto do enfrentamento com a discriminação sofrida internamente quanto das influências externas (SILVA, 2007). Além da efervescência das questóes políticas internas, desencadeadas pelo regime militar, as transformaçóes sociais que compuseram o cenário mundial desde os anos 1960 influenciaram fortemente o processo de organizaçáo das entidades do movimento social negro brasileiro, especialmente a partir do movimento pelos direitos civis nos EUA e das lutas pela independência dos países africanos sob o domínio português.

Do ponto de vista político cultural, emergem entre a juventude afrobrasileira, do Sudeste, especial, mas não exclusivamente, nos estados de Sáo Paulo e Rio de Janeiro, os bailes black, inspirados na soul music norteamericana, como instrumentos de afirmação da negritude e da beleza negra, resgatando a autoestima e fortalecendo identidades, por meio de uma estética rítmica e visual (SILVA, 2007), com uma atitude mobilizadora, veiculando panfletos com mensagens de valorização da negritude inspiradas nos discursos afro-americanos do Black Power e do Black's Beautiful.

Mesmo considerando que essas mobilizaçóes tinham como objetivo principal o lazer, o que, de alguma maneira, as descaracterizavam como movimento de resistência política, não resta dúvida de que foi uma instância importante, por meio da qual um segmento significativo da populaçáo negra adquiriu elementos para a criação de novos símbolos de etnicidade e fortalecimento da consciência de racial.

Em 1971, por iniciativa do poeta gaúcho Oliveira Silveira, um dos líderes do Grupo Palmares, formado na cidade de Porto Alegre, no Rio Grande do Sul, por universitários negros e negras, o dia 20 de novembro começou a ser discutido como o marco principal da resistência negra, pois representa o dia da morte de Zumbi, último líder dos quilombolas palmarinos, em 1695, contestando a importância do dia 13 de maio, de 1888, data oficial de assinatura da Lei Áurea, que aboliu oficialmente a escravidão no país, sem prever um destino digno aos descendentes de africanos libertos. 


\section{Blocos Afro e afirmação da identidade negra}

Cabe ressaltar também, nesse processo organizativo, a criação de grupos que desenvolviam atividades políticas e culturais de valorização da negritude, por meio de uma linguagem rítmica e estética, baseada em valores africanos. Especialmente, a Sociedade Cultural Bloco Afro ILE AIYÊ, criado em 1974, no Curuzú/Liberdade, bairro de maioria negra de Salvador, com propostas de valorização da autoestima da populaçáo negra através da explicitação de aspectos culturais e políticos das naçóes africanas em seus enredos carnavalescos. Em 1975, o Ilê Aiyê saiu às ruas cantando a valorização do povo negro com a música $Q u e$ Bloco é Esse, do compositor Paulinho Camafeu. A música, além de afirmação da identidade negra, tem um tom provocativo.

É o mundo negro que viemos cantar pra você

Branco se você soubesse o valor que preto tem,

Tu tomava banho de piche e ficava negro também

Eu não te ensino minha malandragem

Nem táo pouco minha filosofia

Quem dá luz a cego é bengala branca e Santa Luzia

O fato causou incômodo às elites brancas baianas. Um desfile carnavalesco somente com negros e negras, desafiando a hegemonia do trio elétrico, afirmando a identidade negra e denunciando o racismo, provocou reaçóes críticas de vários setores socioculturais. Segundo reproduziu o saudoso poeta e militante baiano Jonatas Conceição, o jornal $A$ Tarde, órgão da imprensa baiana, publicou artigo classificando o Ilê Aiyê como bloco do racismo, que teria proporcionado "[...] um feio espetáculo no carnaval, com imitação norte americana, falta de imaginação e utilização imprópria do tema"

Pela própria proibição no país contra o racismo, é de se esperar que os integrantes do Ilê voltem de outra maneira no próximo ano, e usem em outra forma, a natural liberação do instinto do Carnaval. Não temos felizmente problema racial. Esta é uma das grandes felicidades do povo brasileiro. A harmonia que reina entre as parcelas de diferentes etnias, constitui, está claro, um dos motivos da inconformidade dos agentes de irritação que bem gostariam de somar aos propósitos da luta de classes, o espetáculo da luta de raças... (BLOCO racista... 1975, p. 3). 
$\mathrm{Na}$ trilha do Ilê Aiyê foram criados outros blocos afros, na Bahia e em outros estados, retratando a importância de heróis e heroínas, negros e negras do Brasil ou da África, como forma de contribuir pedagogicamente com o fortalecimento da consciência negra e com a inclusão desses personagens no sistema educacional brasileiro.

\section{Contra a democracia racial}

Essa postura crítica, resultante de um conjunto de fatores sociais e políticos, tanto internos quanto externos, posto que o país encontrava-se ainda sob as regras do regime de exceção, repercutiu na mudança de atitude do movimento negro, que passou a dialogar qualitativamente com outras instâncias do movimento social e com setores diversos da sociedade brasileira, estimulando posturas mais contundentes e explícitas de denúncia contra o racismo, reivindicação dos direitos de cidadania e também novas reflexóes acadêmicas, especialmente no campo das Ciências Sociais, sobre as questôes de negritude e identidade étnica.

Um marco fundamental foi a criação do Movimento Negro Unificado Contra a Discriminação Racial (MNUCDR), em 1978, em São Paulo, como consequência de uma série de debates desenvolvidos pelas organizaçóes do movimento negro em várias regióes do país, enfatizando a necessidade de organização em nível nacional, com forças suficientes para canalizar as lutas contra o racismo.

Além dos debates que mobilizavam as diversas organizaçóes, dois fatores alimentaram os anseios de atribuir um caráter nacional ao movimento. Em 18 de junho de 1978, Robson Silveira da Luz, um feirante negro de 27 anos, foi torturado e morto por policiais militares do $44^{\circ}$ departamento de polícia de Guaianazes, zona leste de São Paulo, acusado de roubar frutas em seu local de trabalho. Algumas semanas mais tarde, um grupo de quatro jovens negros foi impedido de permanecer nas dependências sociais do Clube de Regatas Tietê, em São Paulo, onde praticavam esportes. Nascia, então, o Movimento Negro Contra a Discriminação Racial (MNUCDR), que saiu às ruas em um gigantesco ato público, realizado no dia 7 de Julho de 1978, nas escadarias do Teatro Municipal de São Paulo. Apresentava sua Carta Aberta à População, onde se lia.

Hoje estamos na rua numa campanha de denúncia. Campanha contra a discriminação racial, contra a opressão policial, contra o desemprego, o subemprego, e a marginalização. Estamos nas ruas para denunciar as péssimas condiçôes de vida da comunidade negra. Hoje é um dia histórico. Um novo dia começa a surgir para o negro! 
Estamos saindo das salas de reunióes, das conferências e estamos indo para as ruas. Um novo passo foi dado contra o racismo. (Movimento Negro Unificado, 1988, p. 8).

No seu primeiro congresso realizado no Rio de Janeiro, em 1979, o nome da organização foi modificado, adotando a denominaçáo Movimento Negro Unificado (MNU). Em 20 de novembro de 1979, o MNU promoveu pela primeira vez atividades relativas ao Dia Nacional de Consciência Negra em São Paulo, estimulando a inclusão do dia 20 de novembro nas agendas de todas as organizaçôes do movimento social negro brasileiro, enfatizando a importância histórica de Zumbi dos Palmares. Mesmo sem o reconhecimento oficial, a memória de Zumbi passou a ocupar espaços nas atividades culturais e pedagógicas programadas em várias escolas municipais e estaduais do país, com a participação de integrantes do movimento negro.

Também nos meios acadêmicos, as questôes relacionadas à população negra ganharam maior visibilidade, passando a fazer parte constante dos debates, estudos e pesquisas sobre religião, processos de exclusão e participação política, identidade étnica, expressốes culturais, etc., exigindo novas formulaçôes que dessem conta da sua especificidade. Na dinâmica desse processo, desde meados dos anos 1980, surgiram novas formas organizativas, como o Movimento de Mulheres Negras (NASCIMENTO, 2003; ROLAND, 2000; SOARES, 2000, entre outros), as lutas quilombolas, com estratégias de resistência coletiva pela posse da terra entre os descendentes de africanos escravizados, o movimento Hip Hop, etc.

Merecem registros também, nessa trajetória de lutas do movimento social negro brasileiro, os Encontros de Negros do Norte e Nordeste ${ }^{5}$, articulaçóes que ocorreram ao longo dos anos 1980, onde a temática central das proposiçóes era a educaçáo como mecanismo de formaçáo, qualificação e ascensão social da população negra. Proposiçóes que estão registradas nos anais desses encontros e que têm sido desenvolvidas por organizaçóes do movimento negro atualmente, tanto nas áreas rurais como nas periferias urbanas.

5 O Encontro de Negros do Norte e Nordeste foi uma atividade promovida pelas organizaçóes do movimento negro, com o objetivo de trocar experiências sobre as questôes comuns da populaçáo negra nos estados dessas regióes bem como socializar as experiências específicas de cada organizaçáo. Durante dez anos, do início dos anos 80 até a década de 90 do século XX, foram realizados encontros na Bahia, Paraíba, Pernambuco, São Luís, Alagoas, Sergipe, Pará e Manaus, onde a temática principal dos debates era a educação da população negra brasileira. 


\section{Ativistas negros e novos diálogos com o estado}

Essas articulaçôes promoveram novas dinâmicas nas organizaçôes do movimento negro, redefinindo estratégias de ação na reivindicação pela igualdade de oportunidades. Alguns ativistas, como Ivair Augusto dos Santos e Hélio Santos, em São Paulo, Diva Moreira, em Minas Gerais, entre outros e outras, ganharam projeção e visibilidade, abrindo portas de diálogos do movimento negro com as instâncias do poder, por meio dos Conselhos e Coordenadorias Estaduais e Municipais da Comunidade Negra criados em alguns estados a partir da década de 80 do século XX.

Em 1984, foi criado o Conselho de Participação e Desenvolvimento da Comunidade Negra do Estado de Sáo Paulo, com o objetivo de acompanhar a eficácia da legislação voltada para os interesses da população negra, apresentar propostas aos setores legislativo e executivo e investigar denúncias de racismo e violência policial. Os Conselhos foram criados no início da redemocratização do país, pós-governo militar, que era, na concepção dos ativistas, conforme mostra Telles (2003), um momento propício para reunir grupos de líderes negros na construção de caminhos para emancipação da população negra.

Para Silva Jr. e Bento (2003), a criação do Conselho de Participação e Desenvolvimento da Comunidade Negra do Estado de Sáo Paulo possibilitou a descentralização das açóes, mediante a criação de Delegacias Regionais e núcleos, subordinados às prefeituras no interior do estado, além das comissóes e grupos de trabalho abrangendo os diversos setores sociais, como saúde, educação e justiça na capital paulista.

Influenciados pelo Conselho paulistano, foram criados outros órgãos dessa natureza em diversas regiōes do país, como Rio Grande do Sul e Rio de Janeiro, Mato Grosso do Sul, Espírito Santo, Minas Gerais, entre outros. Todos enfrentaram uma série de empecilhos para sua instalação, tendo que se confrontar com as acusaçóes de separatismo e acirramento do racismo no Brasil pelos defensores da democracia racial ${ }^{6}$, que insistem em negar a existência de preconceito racial no Brasil.

O sociólogo argentino Carlos Hasenbalg (1979) mostra que, desde o final do Segundo Império e início da República, já se afirmava a inexistência de

6 A ideia da democracia racial brasileira foi desenvolvida a partir da obra Casa Grande e Senzala, do sociólogo pernambucano Gilberto Freyre, que afirmava a existência de relaçóes harmoniosas entre senhores e escravizados no Brasil, defendendo ainda a miscigenação como um símbolo importante da cultura brasileira. Ora, a ideia de povo miscigenado minimiza a importância das desigualdades e dos conflitos raciais (TELLES, 2003; D’ADESKY, 2001). 
preconceito racial no Brasil. Essa concepção tem origem na comparação feita na época entre a situaçáo racial do Brasil e dos Estados Unidos da América do Norte. Tal comparação era feita também pelas elites de outros países da América Latina, com a realidade estadunidense.

Entretanto, explica Hasenbalg (1979), a diferença é que, no Brasil, existe um projeto nacional de branqueamento da população por meio da miscigenação, promovida com o incentivo à imigração de europeus. Dessa forma, a miscigenação acaba servindo para reafirmar a ausência de preconceito e discriminação racial.

Trata-se, de fato, da permanência da suposição da superioridade branca, pois a miscigenação seria a saída para o branqueamento, tanto do ponto de vista genético quanto do ponto de vista cultural, na medida em que, como afirma Florestan Fernandes (1978), esses mecanismos não promovem nem a ascensão social dos negros, nem a igualdade racial, mas, ao contrário, perpetuam a hegemonia da raça dominante.

\section{Rendição ou reconhecimento}

Talvez pelas características de uma sociedade forjada sob o mito da democracia racial, que invisibiliza as contradiçóes vivenciadas pela população negra, o diálogo entre militantes e intelectuais negros e negras com o poder instituído é marcado por muitas controvérsias, principalmente no interior do movimento negro. Porém, seja no plano das reivindicaçôes políticas, seja das manifestaçôes lúdicas, possibilitou a inclusão das questôes raciais nas pautas dos governos, chamando a atenção para os processos de exclusão da população negra na vida sociopolítica do país, alicerçando algumas conquistas atuais. Esse diálogo, a partir dos Conselhos, teve início nos primeiros anos da década de 1980, e pode ser atribuído, entre outros fatores, à qualificação de ativistas de várias organizações do movimento negro nos cursos acadêmicos, especialmente nas áreas das Ciências Humanas, cujas atuaçôes possibilitaram ampliação, não somente dos debates, ao nível nacional, mas também, o estabelecimento de conexôes com organizaçóes antirracistas internacionais.

Do ponto de vista do movimento negro, entretanto, havia muita desconfiança e até acusação de cooptação sobre esses órgãos. Segundo Ivair Alves dos Santos (apud ALBERTI; PEREIRA, 2007, p. 216-217):

As pessoas viam a criação de um órgão de governo do negro, como um órgão que ia contribuir com o racismo. Naquela 


\begin{abstract}
época ainda era vigente a Lei Afonso Arinos ${ }^{7}$. Então a tarefa toda era convencer os outros de que aquele órgáo ia fazer política para combater o racismo [...] Mas o conselho não surgiu de uma demanda do movimento negro. Muitos negros tinham o entendimento de que aquilo poderia ser uma FUNAI, ou alguma coisa que fosse tutelar os negros. [...] havia uma tensão muito grande, pelo seguinte: qualquer participaçáo no Estado era uma cooptação, [...] isso nos impediu, por exemplo, de ter uma aproximação maior com o movimento, que ficou muito desconfiado com o que ia ser aquilo ali.
\end{abstract}

Ora, grande parte dos militantes do movimento social negro que se reorganizava a partir dos anos 1970 tinha suas origens nos movimentos sociais, movimento estudantil e partidos políticos de esquerda, com orientaçóes marxistas. Pesam ainda na memória histórica das organizaçóes negras brasileiras dois fatos importantes, o golpe do Estado Novo de Getúlio Vargas, de 1937, que extinguiu a Frente Negra Brasileira, e a ditadura militar de 1964, que desarticulou as forças mobilizadoras dos movimentos sociais; portanto, as relaçôes dos movimentos sociais, e no caso brasileiro, especialmente as relaçóes do movimento negro com o Estado têm sido caracterizadas por situaçôes de confronto e oposição. Além do que, levando-se em conta que o Estado brasileiro, sempre se articulou com muita eficácia para desmobilizar as lutas da população negra contra o racismo e a discriminação racial por meio do discurso da mestiçagem, é de se esperar que a criação de Conselhos, Coordenadorias ou Secretarias na própria estrutura do Estado, ainda que ocupados por ativistas negros e negras, provoque reaçóes de desconfiança entre os integrantes do movimento negro. Mas, se ficarmos presos à ideia de cooptação, estaremos perdendo a oportunidade de intensificação do diálogo, correndo o risco de autoaprisionarmo-nos em uma camisa de força, reeditando as dificuldades enfrentadas pelas organizaçóes que nos antecederam.

Não se pode perder de vista, entretanto que, se ao final dos anos 1980 algumas organizaçóes passaram a elaborar projetos para suas atividades, caracterizando-se como Organizaçôes Não Governamentais (ONGs), atuando inclusive com recursos de instituiçóes internacionais, a maioria das organizaçóes que compóe o movimento negro nacional é caracterizada, historicamente, pela militância voluntária de seus

7 Lei no 2.390, de 03 de julho de 1951, criada pelo então deputado federal Afonso Arinos de Mello Franco, que incluía entre as contravençóes penais as práticas de preconceito e discriminação racial. Sobre isso, ver: "Legislação", em: <www.senado.gov.br>. 
membros, demarcando sua autonomia e independência em relação ao Estado. Talvez por haver se estruturado dessa forma, a presença de ativistas oriundos das organizaçóes negras em órgãos estatais tenha provocado reaçóes de descontentamento, desconfiança e até acusação por parte de militantes mais radicais no sentido de que aqueles estariam se branqueando, pois o Estado é a representação de um discurso oficial de invisibilização do negro na constituição da sociedade brasileira.

Paradoxalmente, essa suspeita recaia, também, sobre os intelectuais negros e negras que estivessem na qualidade de estudantes ou docentes nas universidades, como se fossem portadores e portadoras de um discurso destituído da prática nas lutas contra o racismo. A meu ver, essas atitudes são contraditórias e podem até limitar as ações do Movimento Negro, pois se por um lado é importante manter a autonomia, não se pode perder de vista, também, a necessidade de dialogar de forma qualificada com o Estado, caso contrário, as reivindicaçôes se esvaem, sem resultarem na implantação de políticas públicas de emancipação da população negra.

Sem dúvidas, mesmo com todos os entraves possíveis de se identificar, foi por meio da participação dos negros e negras nos Conselhos e em outros órgáos criados nos estados, municípios e até no governo federal, especialmente nos períodos mais recentes, embora de curta duração, 2003-2008, que muitas açôes foram implantadas no plano das políticas públicas de valorizaçáo e reconhecimento da importância da população negra na sociedade brasileira.

Esse processo de reivindicaçóes mais qualificadas se deu, especialmente, pelas possibilidades de acesso crescente, de homens e mulheres oriundos das organizaçôes negras nos cursos de pós-graduação das universidades brasileiras. Mesmo que não tenham ainda a visibilidade adequada e estejam longe de atingir percentuais condizentes com o universo populacional negro, é crescente o número de intelectuais negros e negras pesquisando e produzindo conhecimento em várias universidades brasileiras, o que tem possibilitado importantes articulaçóes em níveis da participação em congressos, seminários, ou mesmo de órgáos governamentais, contribuindo para fortalecer as propostas de implantação de políticas inclusivas para a população negra.

Como resultado dessas atuaçóes, podemos relacionar: a inclusão de leis antirracistas na Constituição de 1988; a criação da Fundação Cultural Palmares, no governo de José Sarney, em 1988; o Programa Nacional de Direitos Humanos, em 1996, do Grupo de Trabalho Interministerial (GTI) para o desenvolvimento de Políticas Públicas de Valorização da População Negra (TELLES, 2003), resultante do Seminário Internacional sobre Multiculturalismo e Racismo, financiado pelo Ministério da Justiça; o programa Diversidade na Universidade, ainda no Governo Fernando Henrique Cardoso, em 2001, com o objetivo de criar estratégias que oportunizassem o ingresso e a permanência de negros negras e indígenas na 
universidade, o que significava dizer, na prática, o incentivo a cursos pré-vestibulares e a premiaçáo de estudantes que tivessem ingressado na universidade.

A partir de então, seguindo pistas já lançadas pelo Núcleo de Consciência Negra, da Universidade de São Paulo, em 1992, propondo reparaçóes, inclusive por meio de açóes jurídicas, as organizaçóes do movimento social negro passaram a reivindicar, explicitamente, a implantação de políticas de promoção da igualdade racial. A despeito de reaçóes mais radicais de algumas lideranças de esquerda, que interpretavam as reivindicaçóes por inclusão como integracionistas, essas açóes contribuíram para que os debates sobre políticas de promoção da igualdade racial na educação e no mercado de trabalho adquirissem mais visibilidade na sociedade brasileira, para além de militância negra, ocupando espaços de debates na academia e na sociedade civil.

Cabe ressaltar, do ponto de vista dos diálogos internacionais, a representativa participação da delegação brasileira na Conferência Mundial contra o Racismo, Discriminaçáo Racial, Xenofobia e Intolerância Correlata, em Durban, na África do Sul, em 2001. A Conferência de Durban foi um marco decisivo para, entre outras coisas, a instauração do debate sobre as cotas raciais na mídia e nas universidades públicas brasileiras, tema explicitado a partir de um conjunto de propostas construídas nas reunióes preparatórias à Conferência, ocorridas desde 2000, em várias regióes do país. ${ }^{8}$

Reafirmando a importância da criação de fóruns específicos da intelectualidade negra, comprometidos com a produção de conhecimento sobre a realidade étnicoracial no país, tivemos, a partir do ano 2000, a organização do Congresso Brasileiro de Pesquisadores Negros e Negras (COPENE), evento bianual que tem, entre seus objetivos, trocar experiências, consolidar e legitimar o conhecimento produzido por intelectuais negros e negras, dando visibilidade às produçóes acadêmicas com o recorte étnico-racial. Desde a realização do primeiro COPENE em RecifePE, foi criada a Associação Brasileira de Pesquisadores Negros (ABPN), visando dar sustentação à realização dos Encontros e assegurar melhores condiçóes de produção científica aos pesquisadores e pesquisadoras.

Especialmente a partir do III COPENE, realizado em São Luís do Maranhão, em setembro de 2004, intensificaram-se as articulações entre os Núcleos de Estudos Afro brasileiros (Neabs) com a Secretaria de Educação Superior (SESU), do Ministério da Educação, criando o Programa Uniafro?,

8 SILVA JR; BENTO (2003, p. 14).

9 Programa criado no Ministério da Educação sob Orientação da Secretaria de Educação Superior (SESU) para dar sustentação aos Núcleos de Estudos Afro Brasileiros. 
voltado para a implementação de políticas de açóes afirmativas nas universidades públicas brasileiras, sob a coordenação dos diversos núcleos, centros e programas dessa natureza.

Como consequência das reivindicaçóes históricas desencadeadas pelo Movimento Social Negro, o Presidente Lula criou a Secretaria Especial de Promoção de Igualdade Racial (SEPPIR) e, em janeiro de 2003, sancionou a Lei 10.639, alterando a Lei de Diretrizes Básicas da Educação (LDB) n. ${ }^{\circ}$ 9.394/96 e tornando obrigatório o ensino do conteúdo História da África e Cultura Africana e Afro-Brasileira no currículo oficial da rede de ensino (BRASIL, 2003).

\section{Considerações finais}

Podemos considerar que a dinâmica das transformaçóes sociais das últimas décadas apresentou novas questóes merecedoras de intervençôes mais efetivas do Estado brasileiro, no que diz respeito à superação das desigualdades raciais.

No momento, portanto, em que as sociedades humanas enfrentam uma série de mudanças determinadas pelo processo de globalização, repercutindo em novas formas de organização social, o reconhecimento das injustiças cometidas historicamente contra os descendentes de africanos escravizados e a implantaçáo de ações afirmativas de reparação dessas injustiças constituem um caminho eficaz para que o Estado brasileiro se inclua nesse processo de democratização, superando o racismo e as desigualdades étnico raciais.

Entretanto, embora reconheçamos algumas conquistas importantes, esse processo não está acabado. $\mathrm{O}$ principal entrave à superação das desigualdades sociocracias no Brasil é o racismo institucional, que exige, ainda, açóes mais efetivas para o enfrentamento e superação do racismo. Segundo dados mais recentes do IBGE, a população negra constitui $54 \%$ da população brasileira. Ora, se não estamos representados nessa proporção no parlamento nacional, onde se tomam as decisóes sobre os destinos do país, se não estamos entre os juízes e promotores, se não estamos sequer entre os gestores da administração pública, do país... As políticas de cotas que foram criadas para acesso ao ensino superior e ao mercado de trabalho, como reconhecimento das injustiças históricas cometidas contra a população negra, não são respeitadas, avolumando a usurpação fraudulenta dos nossos direitos por aqueles que se habituaram a usufruir de privilégios. As comunidades quilombolas não têm seus direitos às terras reconhecidos, mesmo estando assegurados na Constituiçáo Federal. E, principalmente nas questôes que nos trazem aqui, se a Lei 10.639/03 não é cumprida, possibilitando novas posturas didático-pedagógicas que nos levem a conhecer melhor a realidade brasileira do 
ponto de vista de diversidade plurirracial, é preciso reconhecer que o racismo institucional orienta nossas ações, camuflando-se nos discursos da mestiçagem e da democracia racial.

O racismo institucional acontece na saúde, na educação, na segurança e na busca por oportunidades de emprego. É, portanto, ao racismo institucional que atribuímos a recusa dos nossos gestores e gestoras em promover a aplicação da Lei, é o mesmo racismo institucional que os profissionais da educação se recusam a estudar e aprender sobre os povos e culturas africanas para além dos navios negreiros e, mesmo sem conhecimento, adotam uma pedagogia predatória de demonização das religióes de matriz africana, ignorando que os demônios são criaçôes do próprio cristianismo, que ampliava seu poder político no primeiro século depois de cristo, combatendo o politeísmo romano.

Orientado pelo mito da democracia racial e pelas ideologias da mestiçagem e da eugenia, o racismo institucional representa o fracasso das instituiçóes públicas brasileiras na implantação de políticas públicas de inclusão étnico-racial, reforçando preconceitos e racismos que estruturam as relaçóes sociorraciais em nosso país, dificultando a superação das desigualdades e das possibilidades de aproveitamento da capacidade prática e intelectual dos descendentes de africanos escravizados no processo de desenvolvimento do país.

Nesse sentido, o desafio que se coloca neste diálogo é de superação das barreiras do racismo, seja no interior das organizaçóes, seja no plano acadêmico ou da gestão e assessoria pública, no sentido de compreender que nenhum país se desenvolve do ponto de vista da democracia da economia ou de cultura enquanto a maioria da sua populaçáo permanecer alijada do processo produtivo por questôes de religião, sexo, origem biológica ou de raça, como é o caso do Brasil.

Do ponto de vista das organizaçóes negras brasileiras, homens e mulheres têm se empenhado historicamente nas lutas contra o racismo, fazendo valer as heranças dos nossos ancestrais, que nunca se renderam à escravidão. $\mathrm{O}$ que pretendemos com esse diálogo é não apenas a sensibilização, mas o comprometimento daqueles e daquelas que acionam frequentemente os discursos dos direitos humanos e da liberdade para que compreendam que esse reconhecimento de direitos e liberdades precisa ser extensivo a todos os que empenharam seus corpos e seus saberes na construção de um país que tem a maior população negra fora do continente africano, que mantém uma rica diversidade, herdada das culturas africanas, seja do ponto de vista lúdico, do idioma falado, da afetividade ou das representaçóes da vida social e, ainda assim, educadores e educadoras insistem no apagamento de capítulos fundamentais da nossa história. Para esses, a África não tem história e os negros nasceram nos navios negreiros. 
Portanto, mais do que uma compensação indenizatória, a implantação efetiva da Lei 10.639/03 tem o objetivo de proporcionar condiçóes para o desmonte, mediante processos educativos, do estigma de inferioridade que carrega a população negra no Brasil, educando brancos e negros e, dessa forma, contribuir efetivamente para a instituição de uma sociedade mais igualitária, pluriétnica e democrática, em que sejam reconhecidas as especificidades de cada grupo componente da nossa população e a eles seja conferido o mesmo grau de importância.

\section{Referências}

ALBERTI, Verena; PEREIRA, Amilcar A. (Org.). Histórias do movimento negro no Brasil: depoimentos ao CPDOC. Rio de Janeiro: Pallas/CPDOCFGV, 2007. 528p.

ALVES FILHO, Ivan. Memorial dos Palmares. Rio de janeiro: Xenon, 1988.

BARBOSA, Márcio; BARBOSA, Aristides. (Org.). Frente Negra Brasileira: depoimentos: projeto de dinamização de espaços literários afro-brasileiros. São Paulo: Quilombhoje, 1998.

BLOCO racista, nota destoante. A tarde. Salvador, BA, p. 3, 12 fev. 1975.

BRASIL. Presidência da República. Casa Civil. Subchefia para Assuntos Jurídicos. LEI n. 10.639, de 9 de janeiro de 2003. Altera a Lei no 9.394, de 20 de dezembro de 1996, que estabelece as diretrizes e bases da educação nacional, para incluir no currículo oficial da Rede de Ensino a obrigatoriedade da temática "História e Cultura Afro-Brasileira", e dá outras providências. Disponível em: < http://www. planalto.gov.br/ccivil_03/leis/2003/110.639.htm>. Acesso em: 5 ago. 2017.

D’ADESKY, Jacques. Pluralismo étnico e multiculturalismo: racismos e antiracismos no Brasil. Rio de Janeiro: Pallas, 2001.

FERNANDES, F. A integraçáo do negro na sociedade de classes. 3. ed. São Paulo: Ática, 1978. v. 2.

FREYRE Gilberto. Casa Grande e Senzala. Rio de Janeiro: Schmidt Editor, 1933.

FREITAS, Décio. Palmares - A Guerra dos Escravos, Ediçóes Graal, 1982.

GUIMARÃES, Antonio Sérgio Alfredo; HUNTLEY, Lynn (Org.). Tirando a máscara - ensaios sobre o racismo no Brasil. São Paulo: Paz e terra, 2000.

HASENBALG, Carlos. Discriminaçáo e desigualdades raciais no Brasil. Rio de Janeiro: Graal, 1979. 
MATTOSO, Kátia de Queirós. Ser escravo no Brasil. São Paulo: Editora Brasiliense, 2001.

MELLO E SOUZA, Marina de. Reis negros no Brasil escravista: história de festa e coroação de Rei Congo. Belo Horizonte: Editora UFMG, 2002. 387p.

MOURA, Clóvis. Brasil: as raízes do protesto negro. São Paulo: Global Editora, 1983.

MOURA, Clóvis. Dicionário da escravidão negra no Brasil. São Paulo: Editora da Universidade de São Paulo, 2004.

MOURA, Clóvis. Sociologia do negro brasileiro. São Paulo: Ática, 1988. (Série Princípios).

MOVIMENTO NEGRO UNIFICADO: 1978-1988 - 10 anos de luta contra o racismo. São Paulo: Confraria do Livro, 1988.

NASCIMENTO, Elisa Larkin. O sortilégio da cor: identidade, raça e gênero no Brasil. São Paulo: Selo Negro, 2003.

NASCIMENTO, Abdias do; NASCIMENTO, Elisa Larkin. Reflexôes sobre o movimento negro no Brasil (1938-1997). In: GUIMARÃES, Antônio Sérgio Alfredo; HUNTLEY, Lynn (Org.). Tirando a Máscara - ensaios sobre o racismo no Brasil. São Paulo: Paz e Terra, 2000.

QUINTÁO, Antonia Aparecida. Irmandades Negras: outro espaço de luta e resistência. (São Paulo: 1870-1890). São Paulo: Annablume/ FAPESP, 2002.

RIOS, Flávia Mateus. Movimento negro brasileiro nas Ciências Sociais (15002000). Sociedade e Cultura, Goiânia, v. 2, p. 263/274, jul./dez., 2009.

ROLAND, Edna. O movimento de mulheres negras brasileiras: desafios e perspectivas. In: GUIMARÃES, Antonio Sérgio Alfredo; HUNTLEY, Lynn. (Org.). Tirando a Máscara - ensaios sobre o racismo no Brasil. São Paulo: Paz e terra, 2000.

SANTOS. Joel Rufino. Saber do Negro. Rio de Janeiro: Pallas, 2015.

SANTOS, Sales Augusto dos. Educação: um pensamento negro contemporâneo. Jundiaí: Paco Editorial, 2014.

SILVA, Carlos Benedito R da. Ritmos da Identidade: mestiçagens e sincretismos na cultura do Maranhão. São Luis: SEIR/FGAPEMA/EDUFMA, 2007.

SILVA JR, Hédio; BENTO, Maria Aparecida Silva. O papel da cor: raça/etnia nas políticas de promoção da igualdade. São Paulo: CEERT, 2003. 
SOARES, Marisa de Carvalho. Devotos da cor. Rio de Janeiro: Civilização Brasileira, 2000.

SOUZA, Jessé. Multiculturalismo e Racismo: uma comparação Brasil- Estados Unidos. Brasília-DF: Ministério da Justiça. Secretaria Nacional de Direitos Humanos, 1997.

TELLES, Edward. Racismo à brasileira: uma nova perspectiva sociológica. Rio de Janeiro: Relume Dumará/Fundação Ford, 2003. 